\title{
Layered Learning, Eustress, and Support: Impact of a Pre-Service-Learning Training on Students' Self-Efficacy in Teaching in the Community
}

\author{
Natalie K. Cooke, ${ }^{1}$ Anne K. Pursifull, ${ }^{2}$ Kerry M. Jones, ${ }^{2}$ and L. Suzanne Goodell ${ }^{3}$
}

\begin{abstract}
Service-learning programs provide students with opportunities to gain discipline-specific skills, while providing community organizations with a steady pool of volunteers. However, because students may lack the skills needed to effectively serve the community, skills-based training may need to be incorporated into service-learning courses. Students in a community nutrition service-learning course engaged in 7 weeks of training before teaching a 6-week-long nutrition education course to community members. The training included three layers of activities: (1) basic activities, which introduced the students to material necessary to build skills for their service-learning experience; (2) directed activities, which allowed them to refine a targeted skillset; (3) and collective activities, which allowed for the application of multiple skills. Through qualitative interviews with 12 of the 19 students who had been enrolled in the course, we determined the impact of a pre-service-learning training program on the development of the skills necessary to successfully teach a nutrition education course. Thematic analysis of the data revealed two major themes: (1) "layered learning" activities facilitate skill building and (2) a stressful, yet supportive, environment facilitates growth. Together, these aspects of course design allow students to develop skills and their self-efficacy in those skills. Therefore, instructors who plan to incorporate servicelearning into their nutrition courses may benefit from designing a pre-servicelearning training to improve student learning outcomes.
\end{abstract}

Keywords: service-learning, self-efficacy, educational theory

\section{Introduction}

Many community-based organizations and nonprofits rely on volunteers to expand their educational reach, and often universities are looking for ways to connect their students with meaningful experience in the community. One way to meet both goals is to develop servicelearning programs. Service-learning is both a type of experiential education and pedagogy that combines academic content, relevant service in the community, and critical reflection of the learning experience (Eyler \& Giles, 1999). Service-learning partnerships should be mutually beneficial for students and community members and include clear expectations for student involvement (Bringle \& Hatcher, 1995). Through the combination of academic learning, relevant

\footnotetext{
${ }^{1}$ Teaching Assistant Professor, Department of Food, Bioprocessing, and Nutrition Sciences, North Carolina State University, Campus Box 7624, Raleigh, NC 27695, nkcooke@ncsu.edu

${ }^{2}$ Undergraduate Researcher, Department of Food, Bioprocessing, and Nutrition Sciences, North Carolina State University, Raleigh, NC

${ }^{3}$ Associate Professor, Department of Food, Bioprocessing, and Nutrition Sciences, North Carolina State University, Raleigh, NC
} 
service, and critical reflection, students can grow in their understanding and application of knowledge in the community, their own personal characteristics, and their ability to interact with and understand how community partnerships function (Ash, Clayton, \& Moses, 2008). In addition to providing students with an opportunity for personal, academic, and civic growth, servicelearning programs benefit instructors, community organizations, and participants in the community programs. Instructors are able to provide students with an opportunity to significantly improve their abilities without sacrificing additional classroom time (Tucker \& McCarthy, 2001), while community organizations are able to increase their capacity to serve clients while also identifying potential future employees (Driscoll, Holland, Gelmon, \& Kerrigan, 1996).

However, because undergraduate students are not professionals in their fields, they may need additional training before they begin their service-learning experience, especially when the service is related to teaching discipline-specific information in a community-based setting. Many small- to medium-sized community-based organizations lack the staff and time to train students (Tryon et al., 2008), so university instructors should design skills-based training to accompany the service-learning experience. Guides for creating service-learning programs reference the need to orient students to the service-learning experience through training (Bringle \& Hatcher, 1995; Yoder, 2006), but parameters about the length or extent of this orientation are not documented. These training programs could be used to not only introduce students to the service-learning experience but also to increase their self-efficacy, or confidence in their ability to perform skills (Bandura, 1977), related to the service-learning experience before the experience begins. According to Bandura, the four sources of self-efficacy are: vicarious learning (seeing someone else perform a similar task), mastery (the process by which one practices and masters a skill), verbal persuasion (receiving feedback about performance), and physiological/emotional arousal (the current state of the body and mind while mastering the skills). Self-efficacy can play a crucial role in a successful, mutually beneficial service-learning experience. When a student's selfefficacy is high, he or she will put in more effort, persist longer in the face of obstacles (Bandura, 1977), and perform better (Bruning, Schraw, \& Norby, 2010), all of which benefit the community partner and community participants. It has been established that service-learning programs increase students' self-efficacy in teaching (Bernadowski, Perry, \& Del Greco, 2013; Cooke et al., 2015), and field experiences play an essential role in developing pre-service teachers' teaching skills (Ben-Peretz, 1995; Bernadowski et al., 2013). Then, to what extent would a pre-servicelearning training program prepare students for teaching in the community? Specifically, what is the impact on their teaching self-efficacy?

Through an iterative process of development, implementation, and revision, the first and fourth authors developed a pre-service-learning training program to guide upper-level undergraduate students in learning and practicing skills necessary to be successful during the service-learning experience. Students enrolled in a community nutrition service-learning course engaged in a pre-service-learning training program before implementing a pre-packaged educational curriculum in the community. The pre-service-learning training was designed to improve self-efficacy by targeting Bandura's four sources of self-efficacy: vicarious experience (modeling), verbal persuasion (feedback), mastery (successfully building the skill), and physiological and emotional state (supportive or stressful) (Bandura, 1977). After the pre-servicelearning training, students served as volunteer instructors for the A PACKed Kitchen servicelearning program, locally administering the Cooking Matters cooking and nutrition education Journal of the Scholarship of Teaching and Learning, Vol. 17, No. 3, July 2017. josotl.indiana.edu 
curriculum on behalf of the Inter-Faith Food Shuttle, a local food rescue organization. Cooking Matters is a nationally recognized, six-week curriculum that was developed by Share Our Strength, a national organization dedicated to ending child hunger, to teach community members how to make healthier choices and affordable meals. The Inter-Faith Food Shuttle is North Carolina's state partner for Cooking Matters, and A PACKed Kitchen is a satellite of the Inter-Faith Food Shuttle. Participants in Cooking Matters classes come from limited resource backgrounds, and the Cooking Matters classes teach them to make the most of their food dollars. Participants range in age from elementary school to senior adults, and nationally, roughly half of the participants take part in at least one form of federal food assistance (Cooking Matters, 2013). Over 7 years, more than 120 upper-level undergraduate students have been a part of A PACKed Kitchen's programming, reaching over 300 limited-resource community participants through Cooking Matters classes and helping to expand the programming of the Inter-Faith Food Shuttle and Share Our Strength.

Having both qualitatively (Goodell, Cooke, \& Ash, 2016) and quantitatively (Cooke et al., 2015) determined that students' self-efficacy increases as the result of the service-learning experience as a whole, we wanted to qualitatively explore the impact of just the pre-servicelearning training program on the development of students' skills and self-efficacy. This paper will report those findings and provide details about the course as an example of a training program model that higher education institutions can use to prepare undergraduates to teach a pre-packaged educational curriculum in a community-based setting.

\section{Methods}

\section{Course Design}

The community nutrition service-learning course was an upper-level nutrition course at North Carolina State University that served as an elective for students majoring or minoring in nutrition. Students typically elected to take the course during their junior or senior year, but the only prerequisite was an introductory nutrition course. The service-learning course consisted of a traditional three day a week, one-hour lecture and a one day a week, four-hour lab/field experience. In the lecture, students learned about planning, implementing, and evaluating nutrition education programs, including the importance of catering to cultural differences in nutrition education. The lab was split into two parts: the pre-service-learning training and the service-learning experience. The first half of the semester consisted of a 7-week-long pre-service-learning training where students participated in activities to build their skills as nutrition educators. We categorize these activities into three "layers": (1) basic, (2) directed, and (3) collective (Table 1). The categories describe what students gained from engaging in the activities. Basic learning activities allowed the students to gain an understanding of fundamental principles they would be asked to apply during the service-learning experience. For example, the Gold Standards video and discussion allowed students to observe and critique discipline-specific teaching techniques. Directed learning activities enabled students to develop one targeted skillset and then practice that specific skillset. For example, in the grocery store budgeting activity, students were tasked with going to the grocery store to develop a budget based on the prices of foods they intended to use during the servicelearning experience, which served as not only a lesson planning activity, but also an opportunity Journal of the Scholarship of Teaching and Learning, Vol. 17, No. 3, July 2017. josotl.indiana.edu 
to better understand the budgetary constraints of community participants. Collective learning activities required students to apply many skills at one time. For example, during the mock lessons, students were charged with implementing a lesson plan they developed earlier in the semester while simultaneously practicing flexibility, public speaking, and time management. The course Table 1. Pre-service-learning-training activity descriptions, organized by week

\begin{tabular}{|c|c|}
\hline Week & Description \\
\hline \multirow{3}{*}{ Week 1} & $\begin{array}{l}\text { Iron Chef Challenge: Students worked in teams to modify a recipe to make it } \\
\text { healthier and include a secret ingredient, while only using cooking supplies provided } \\
\text { to them (e.g. electric burners and skillets). After presenting their ideas to the teaching } \\
\text { team, students then had the remainder of the hour to make the recipe. }{ }^{\text {a }}\end{array}$ \\
\hline & $\begin{array}{l}\text { Introduction to the Service-Learning Experience: Students learned about community } \\
\text { partner agencies through in-person and video presentations. }{ }^{\mathrm{a}}\end{array}$ \\
\hline & $\begin{array}{l}\text { Cooking Matters-At-A-Glance Lesson Planning: This first lesson planning } \\
\text { assignment introduced students to the pre-packed curriculum by having them } \\
\text { complete a one-page diagram of their 6-week teaching plan. }\end{array}$ \\
\hline \multirow[t]{2}{*}{ Week 2} & $\begin{array}{l}\text { Gold Standards Video and Discussion: Students watched video clips of previous } \\
\text { students teaching in the community. As a group, students discussed the effectiveness } \\
\text { of teaching techniques to gain an understanding of nutrition education standards. }{ }^{\text {a }}\end{array}$ \\
\hline & $\begin{array}{l}\text { Lesson Plan Outlines: Using instructor feedback on students' at-a-glance lesson } \\
\text { plans, student teams created more detailed lesson plans for each of the six lessons. }\end{array}$ \\
\hline \multirow{3}{*}{ Week 3} & $\begin{array}{l}\text { Conflict Management: Each student received a unique conflict scenario on a piece } \\
\text { of paper and then collaborated with peers to determine solutions. Afterwards, we } \\
\text { reviewed all scenarios in a large-group discussion. }{ }^{\text {a }}\end{array}$ \\
\hline & $\begin{array}{l}\text { Facilitated Dialogue: Students practiced using open-ended questions with a partner, } \\
\text { competing to be the pair who could keep a dialogue consisting of only open-ended } \\
\text { questions going the longest. }\end{array}$ \\
\hline & $\begin{array}{l}\text { Grocery Store Budgeting: Students went to a grocery store to prepare a budget } \\
\text { spreadsheet for their six-weeks lessons, staying under a certain dollar amount. }{ }^{\text {b }}\end{array}$ \\
\hline Week 4 & $\begin{array}{l}\text { Knife Skills Evaluation: After watching a series of knife skills videos and practicing, } \\
\text { students were evaluated on their knife safety technique and explanation }{ }^{\mathrm{c}}\end{array}$ \\
\hline Week & $\begin{array}{l}\text { Mini Mock Lesson: Using parts of a lesson plan prepared during Week 2, students } \\
\text { taught a 10-minute lesson while peers acted the age of the participants that student } \\
\text { would be teaching in the community, purposefully creating challenges. }{ }^{c}\end{array}$ \\
\hline Week 6 & $\begin{array}{l}\text { Shopping Matters: As a class, the students set up the classroom like a grocery store, } \\
\text { using food labels and empty food packages. The students then led a mock grocery } \\
\text { store tour for the instructors and community liaisons. }{ }^{c} \\
\text { Supplies Inventory: Students received bins with teaching aids and cooking } \\
\text { equipment, so they could take inventory and understand what supplies they had } \\
\text { available for their mock lesson and Shopping Matters class. }{ }^{\text {a }}\end{array}$ \\
\hline
\end{tabular}

Journal of the Scholarship of Teaching and Learning, Vol. 17, No. 3, July 2017. josotl.indiana.edu 


\begin{tabular}{l|l}
\hline Week 7 & $\begin{array}{l}\text { Mock Lesson: Students taught an hour-long modified lesson as a group, while peers } \\
\text { and a guest actors pretended to be participants. Again, the participants created } \\
\text { challenges for the teaching team and to build their teamwork skills. }{ }^{c}\end{array}$ \\
\hline${ }^{a}$ Basic Learning Activity ${ }^{b}$ Directed Learning Activity ${ }^{c}$ Collective Learning Activity \\
\hline
\end{tabular}

was purposefully designed to be rigorous and demanding to prepare students for the flexibility needed to work in a community-based setting.

During the second half of the semester, students taught the 6-week-long pre-packaged Cooking Matters nutrition education and cooking curriculum in the community. Students were assigned to teams of five for the semester, and while students each had their own unique part of the lesson, they were expected to team-teach the entire lesson. Each team was supported by a community liaison (teaching assistant) who served as both a connection to the community partner and a peer performance evaluator. The 7-week pre-service-learning training program design was the result of the iterative process of course evaluation and revision and now includes all four of Bandura's sources of self-efficacy (Cooke et al., 2015).

\section{Participants \& Recruitment}

To determine the effectiveness of the pre-service-learning training, we interviewed students who had been most recently enrolled in the service-learning course at North Carolina State University. We chose to interview only students from one semester because previous semesters did not include the Iron Chef Challenge, an activity that we believed was key to team building. After submitting final grades, we recruited eligible students via e-mail, providing an incentive of a \$10 gift card for participation. The Institutional Review Board at North Carolina State University approved this research.

\section{Data Collection}

Before conducting interviews, we developed a standardized interview guide using a list of the activities and assignments from each week of the pre-service-learning training lab (Table 2). The third author, a community liaison who had assisted with implementing the pre-service-learning training and evaluating students during the service-learning experience, was the sole interviewer. Before conducting interviews, the interviewer engaged in a rigorous, standardized multi-pass interview training, which included how to conduct an interview while remaining unbiased and nonjudgmental, how to use reflexivity to review major discussion points with the participant, and a series of mock interviews to hone interviewing skills (Goodell, Stage, \& Cooke, 2016).

Before beginning each phone interview, the interviewer reviewed the consent form with each participant, and the participant gave verbal consent to participate in the interview. The interviewer followed the standardized interview guide, starting with an icebreaker and then asking about each week's major activities. Finally, the interviewer asked how the overall lab experience helped to prepare the student for their teaching experience. Each phone interview lasted between 30 and 60 minutes, was recorded on an audio recorder, followed the same questioning sequence, and included member checking at the end of each interview (Goulding, 1999).

Journal of the Scholarship of Teaching and Learning, Vol. 17, No. 3, July 2017. josotl.indiana.edu 


\section{Data Analysis}

After each interview, the third author conducted initial analysis and determined preliminary dominant themes. Once the interviews were completed, the second author transcribed them verbatim. Next, the authors developed a coding manual with 26 codes, 13 skills-based codes and 13 activity-specific codes. The skill-based codes consisted of the skills students reported

Table 2. Major interview questions and probes from interview guide

\begin{tabular}{|c|c|}
\hline No. & Question or Probe \\
\hline 1 & What was the funniest thing that happened during the NTR 420 lab? \\
\hline 2a. & $\begin{array}{l}\text { In Week } 1 \text { of the Community Nutrition lab, you completed the Iron Chef Challenge and } \\
\text { got an introduction to A PACKed Kitchen and Cooking Matters. You also watched the } \\
\text { community partner videos made by the community liaisons and completed the Cooking } \\
\text { Matters-at-a-Glance assignment, determining the basic activities and recipes for all } 6 \\
\text { weeks. First, let's talk about the Iron Chef Challenge. }\end{array}$ \\
\hline $2 b$. & $\begin{array}{l}\text { Now let's talk about the introductions to A PACKed Kitchen and Cooking Matters as well } \\
\text { as the community partner videos.* }\end{array}$ \\
\hline 2c. & Now, let's talk about the Cooking Matters-at-a-Glance assignment.* \\
\hline 3a. & $\begin{array}{l}\text { In Week 2, you did an activity with the Cooking Matters Gold Standards by watching } \\
\text { different videos from previous classes and then worked on your lesson plan. First, let's } \\
\text { talk about the Cooking Matters Gold Standards activity.* }\end{array}$ \\
\hline 3b. & Now let's talk about the lesson plan you created with your group.* \\
\hline 4a. & $\begin{array}{l}\text { In Week 3, you did a conflict management activity where you each got a slip of paper with } \\
\text { a conflict scenario from a previous class. Also, you did a facilitated dialogue activity } \\
\text { where you got in pairs and had to ask only open questions for five minutes. Finally, you } \\
\text { got into groups and worked on your Cooking Matters budget. First, let's talk about the } \\
\text { conflict management activity.* }\end{array}$ \\
\hline 4b. & litated dialogue activity.* \\
\hline 4c. & let's talk a \\
\hline 5. & In Week 4, you had knife skills evaluations.* \\
\hline 6. & $\begin{array}{l}\text { In Week } 5 \text {, you had mini mock lessons. This is where you taught a } 10 \text {-minute lesson to } \\
\text { the class, by yourself.* }\end{array}$ \\
\hline 7a. & $\begin{array}{l}\text { In Week 6, you gave a Shopping Matters tour with your classmates to the TAs and course } \\
\text { instructor, and then you needed to give your supplies checklist for your Mock Lesson to } \\
\text { the TA or your community liaison. First, let's talk about the Shopping Matters.* }\end{array}$ \\
\hline 7b. & $\begin{array}{l}\text { Now let's discuss the supplies checklist [where you went through the supplies box] for the } \\
\text { Mock Lesson.* }\end{array}$ \\
\hline 8. & $\begin{array}{l}\text { Week } 7 \text { was the last week before you went out into the community. You taught your mock } \\
\text { lesson as a group to your classmates and guests. Let's talk about the mock lesson.* }\end{array}$ \\
\hline
\end{tabular}

Journal of the Scholarship of Teaching and Learning, Vol. 17, No. 3, July 2017. josotl.indiana.edu 
9a. So, I'd like to recap and give you a chance to comment on the whole training experience in lab. When looking back at the whole lab experience in general, what do you think you gained?*

9b. Looking back, what would you change about lab?

*Probe used after every major interview question: Thinking about skills gained, working with teammates and with the community, how did this benefit you when teaching in the community, if at all?

developing during the pre-service-learning training program. The activity-specific codes were associated with the different activities in the training program. The authors included specific definitions in the coding manual to standardize the coding process and prevent discrepancies in coding. The second and third authors coded the transcripts independently and then reviewed the coded transcripts with the first author. The three authors met weekly to discuss coding discrepancies and came to consensus on a final set of coded transcripts. Reviewing the coded quotes with three researchers ensured consistency in the analysis of the transcripts, reducing coder drift (Bartholomew, Henderson, \& Marcia, 2000). NVivo 9 Qualitative Analysis software was used to organize student quotes falling under each coding category. After reviewing the codes and associated quotes, three of the authors prepared a report of the major findings from the analysis and then discussed the findings. The first author reviewed all three reports, creating the explanatory model from the composite of the three reports, confirming structure through a discussion with the fourth author. Ultimately, two dominant themes emerged from the data, which are depicted in the explanatory model.

\section{Results}

Of the 19 students enrolled in the course, 12 completed interviews. Thematic analysis of the interviews revealed two major themes: (1) "layered learning" activities facilitate skill building and (2) a stressful, yet supportive, environment facilitates growth. Students engaged in "layered learning" that incrementally prepared them for the service-learning experience through basic, directed, and collective activities. The rigor of this training program introduced the students to stressors. However, the supportive environment of the course helped students manage these challenges and ultimately prepared them for the service-learning experience. Figure 1 depicts an explanatory model depicting the factors related to skill building during the pre-service-learning experience.

\section{Theme 1: Layered learning activities facilitate skill building}

Students stated that the layered approach to skill building during the pre-service-learning training program allowed them to build three categories of skills: (1) teaching, (2) discipline-specific, and (3) interpersonal relationship skills. The teaching-specific skills students gained were lesson Journal of the Scholarship of Teaching and Learning, Vol. 17, No. 3, July 2017. josotl.indiana.edu 
planning, time management, communication, and flexibility. Discipline-specific skills included budgeting, knife skills, presenting nutrition content at a basic level, and answering common nutrition-related questions. The interpersonal relationship skills that students gained were teamwork and community awareness.

Teaching skills. Students gained teaching skills from all three types of activities - basic, directed, and collective. All students said that during the training program they developed lesson planning skills and an understanding of the importance of planning. Students believed that preparing in-depth lesson plans during the Lesson Plan Outlines, a directed learning activity, was most beneficial for developing lesson planning skills. Students talked about how doing in depth planning before they began their service-learning experience allowed them to be highly prepared for the experience. One student said: "[Having lesson plans prepared in advance] really benefited us, ... instead of focusing on ... what we are going to teach [that] week, we were able to just glance at [the lesson plan] and fine tune the details ... but we had the core there already, which allowed us to be more prepared." Even though students appreciated the lesson plans during the service-

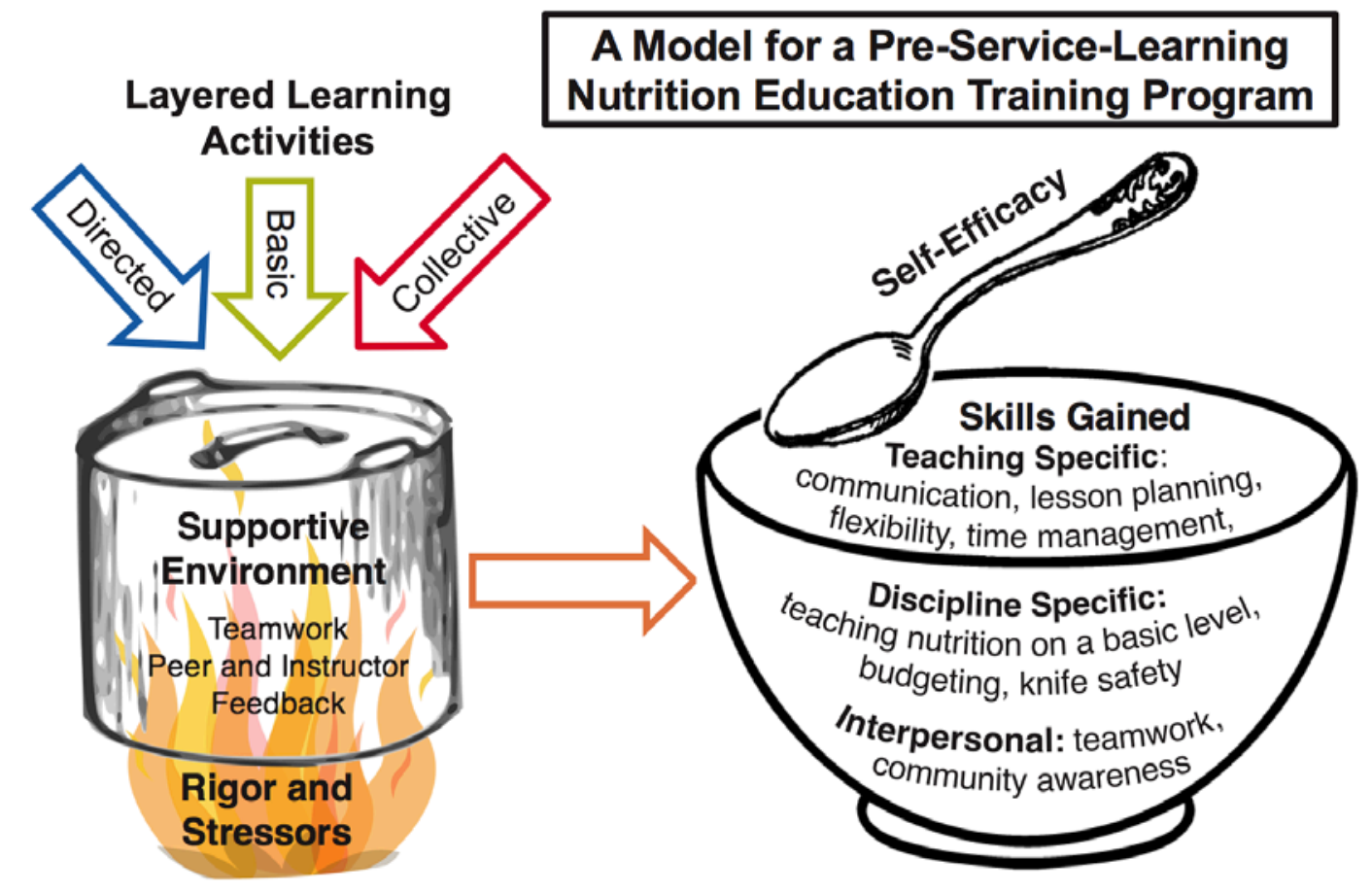

\section{Figure 1. Model for Pre-Service-Learning Training Inputs and Outputs ${ }^{4}$}

learning experience, many were initially frustrated at the scope of the assignment, feeling illprepared to complete it. Some students found it frustrating that they had to complete all their lesson plans during the first two weeks of the pre-service-learning training, but once they started the service-learning experience, they said they were glad to have lesson plans mostly finalized. Even

\footnotetext{
${ }^{4}$ Images from https://openclipart.org (cooking pot by “tom” and fire by “glitch”), www.clipartpanda.com (spoon), and www.imagui.com (bowl) Journal of the Scholarship of Teaching and Learning, Vol. 17, No. 3, July 2017. josotl.indiana.edu
} 
though lesson planning had the potential to be time-intensive and stressful, having lesson plans drafted by the second week of the training program allowed students to adjust and refine their plans throughout the next five weeks. The collective learning activities, such as the mock lessons, provided students with the opportunity to practice teaching nutrition and allow them to discover what teaching and planning techniques would and would not work for them. By having lesson plans completed before these collective learning activities, students could adjust the plans as they learned more about effective teaching techniques.

Like lesson planning, the collective learning activities helped students gain time management skills because they participated in activities that mimicked their service-learning experience. One student said that the time constraints of the mock lessons were helpful because: "It really allowed me to ... consider the most important aspects of my lesson." The collective learning activities provided students with experiences that allowed them to reflect on their lesson plans and think about how they would spend their time during their future lessons.

Students also reported building communication skills during the pre-service-learning training program. Students said the facilitated dialogue activity, a basic learning activity, was most helpful. They said that this activity allowed them to develop their communication skills by learning how to ask open-ended questions and practicing doing so. One student said they discovered "how important asking open ended questions was, because it showed ... how much the kids were actually learning." Students were then able to refine their communication skills by applying what they learned about open-ended questions and the principles of public speaking during the collective learning activities. One student said that the knife skills evaluation was also helpful in building communication skills: "[It was] the first time that we were demonstrating and speaking in front of a group, so it helped with our public speaking, our teaching skills and our knife skills all at once, and it kind of got the nerves out of the way.” The basic learning activities gave students a general understanding of communication concepts so they could effectively apply those concepts during the collective activities and ultimately during their service-learning experience.

Students also learned to be more flexible from the collective learning activities. These activities presented students with opportunities to problem solve and juggle many aspects of teaching at once. Students said that by facing unexpected challenges during mock teaching, such as disobedient mock lesson participants, they could learn how to handle these situations and prepare for similar ones in the future. One student said, "I remember being really frustrated [when classmates pretending to be kids were acting up during the Mock Lesson], because I was like, why couldn't they give us a little bit of slack? But when we went out into the community, we actually had a really rambunctious group of kids, so it was good to ... have already practiced that and ... see how to handle that as a team." A student reflected that these types of activities helped build a realization that "nothing is ever going to go perfectly, and it's important to adapt and make changes so that the participants can learn as much as possible in order to gain from the experience." Through these collective activities, students reported gaining the ability to "think on their feet," learn to remain composed and not panic when difficulties arose, and understand how to answer questions when they were unsure of the answer.

Discipline-specific skills. In addition to the teaching skills, students also gained disciplinespecific skills that they could combine with their teaching skills to have a successful servicelearning experience. Students reported that the budgeting activity, a directed learning activity, taught them about eating healthy on a budget. For example, ingredients in a recipe could be Journal of the Scholarship of Teaching and Learning, Vol. 17, No. 3, July 2017. josotl.indiana.edu 
swapped with less expensive options while still maintaining the healthfulness of the dish. One student reflected, "The recipe called for, I think, almonds. And so almonds were very expensive, so we substituted sunflower seeds instead because they were a cheaper option." Most of the students said that they benefitted from the directed learning budgeting activity because it allowed them to experience the budgeting process and therefore be better equipped to teach budgeting to others. One student said, "If you're going to teach people budget techniques, you're going to have to go through it yourself so you're not just talking about it.”

The students also reported gaining discipline-specific skills of healthy and safe cooking. Many students thought they learned the most about food safety from the collective learning activity where they had to demonstrate knife skills and communication skills simultaneously. One student said, "You wanted to make sure you [demonstrated using a knife] the best way possible. ... Since we were working with kids, knife safety was so important to be able to teach them, and so holding the knife right was kind of ingrained in our brain by that week.” Another student said, "The knife skills [evaluation] really helped me, because it forced me to say [the process of chopping a food] out loud. I think that it kind of gave us an idea, of what it was going to be like it whenever we were telling the kids how to use a knife.” This is an example of how the teaching-specific and disciplinespecific skill building came together through a collective activity.

Some students also discussed how the training program prepared them to teach nutrition concepts on an elementary level, especially during the mock grocery store tour when they were asked a series of tough questions related to nutrients in foods. As a collective activity, the grocery tour pushed the students to utilize prior nutrition and communication knowledge to develop clear and concise answers to student questions on the spot.

Interpersonal Relationship Skills. Students reported gaining community awareness and the ability to work with a team because of the pre-service-learning training program, both skills that had the potential to impact interpersonal relationships with their teams or with their future community participants.

While students had an opportunity to build community awareness throughout the entire course, when discussing the pre-service-learning training, students mainly described the impact of the directed learning activities on developing an understanding of and empathy for community members. Students commented that they could gain a better understanding of their community participants' budgets from the budgeting activity, since they were expected to stay within a tight budget. One student said, "[It] allowed us to ... think of where that specific population would shop ... and it ... had us think more, budget-wise, making sure things were affordable for people, and easily accessible for that group of people.” This directed learning activity also allowed students to realize "that not everybody is going to be [from the same] socioeconomic [background]" and that it was important for students to "communicate that you can eat healthy on a lower budget, ... that it's not an unrealistic feat."

Most of the activities were team-based; therefore, the layered approach to instruction allowed students to build skills in teamwork gradually throughout the pre-service-learning experience. One student said that the first team activity, the Iron Chef Challenge, was beneficial: "Just to be thrown into it like that, with no preparation, trying to make the best dish, was challenging but kind of, I guess helpful for later on. ... We knew that we were able to work as a team after this first week of lab.” One student reported that the collective activities helped them identify problems in their group and allowed them to fix the problems before they taught in the Journal of the Scholarship of Teaching and Learning, Vol. 17, No. 3, July 2017. josotl.indiana.edu 
community. That student said, "[One] group member we saw was talking a lot [during the mock lesson], and didn't really give [another teammate] a chance to talk. We saw that we needed to find a way to deal with that in the classroom later on. I guess it just gave us a preview of what was going to happen in the next few weeks.” Another student thought that the collective learning activities helped their teams work together and prepare to teach in the community because "it also allowed [them] to see how [their] teammates interacted under pressure and stress." Due to the scope of the interview questions, we did not ask the students how these interpersonal relationship skills might have impacted their experience in the community.

\section{Theme 2: A stressful yet supportive environment facilitates growth}

While students were able to build many skills through the pre-service-learning training, the rigor of the program left many students feeling stressed and under pressure to perform well. Some students thought that there were an overwhelming number of time-consuming assignments during the pre-service-learning training. However, students reported that they could endure the stress due to support from their teammates and teachers. By the end of the experience, students reflected that the stressful aspects of the program were key to the development of their skills and fully preparing them for the service-learning experience.

Stressors provide pressure for growth. The activities that the students found to be most stressful during the training program also happened to be the most beneficial in terms of refining skill development and preparing them for work in the community. The activities that students said were most stressful were the two lesson planning activities and the collective learning activities. When students reflected on the training program after the service-learning experience, they recognized that although these activities were rigorous, they were key to preparing them for a successful service-learning experience.

Students found the two directed activities related to lesson planning to be highly stressful. Some students said the activities made them feel like they were thrown into the class. Even though students were given the pre-packaged curriculum as a guide, one of the students described the process of deciding what to include from the curriculum as: "[being given] a blank piece of paper and [told to] jot down what you're going to be teaching in the next six weeks." However, it was necessary that students be briefly overwhelmed by the scope of this activity so that they would put sufficient time and effort into their lesson plan. A well thought out lesson plan is key to a successful service-learning experience. It is used and edited throughout the training program so students can rely on it during their service-learning experience. After the semester was over, students reported that they found making lesson plans in advance very useful for when they began the servicelearning experience. One student said, "Everything we did was, worth it and at the time it could be stressful, but I think it was important to [plan during lab so that when] teaching out in the community we could focus more on the participants and not stress about our lessons. So I think I gained a lot from the lab experience." Even though students claimed to be stressed by this activity, all the teams eventually developed detailed lesson plans that they relied on during the servicelearning experience.

The students also participated in collective activities where they taught practice lessons in front of their peers. Students reported being nervous when practicing in front of peers, but they realized it helped build teaching and communication skills. One student reported that these Journal of the Scholarship of Teaching and Learning, Vol. 17, No. 3, July 2017. josotl.indiana.edu 
activities helped them be "comfortable in front of a crowd and able to - demonstrate how to [use a knife properly]." One student also reported that since she was nervous about the first collective activity, the knife skills evaluation, she spent a lot of time preparing for it. The stress of this activity encouraged her to devote more time to her preparation, so that she was confident in her knife skills by the time of the evaluation. Another student recognized that the extra stress that came with this graded assignment motivated them to master their knife skills before they entered the community and were expected to teach kids how to properly use knives. Even though students found the preservice-learning training to be stressful, they reported that it helped prepare them for the servicelearning experience.

Supportive environment helps relieve the negative effects of stress. Students reported being able to endure the rigor of the training program because of their teammates, feedback from others, critical reflection, and the course design. The pressure of the course requirements presented opportunities for students to build teamwork. One student discussed working on the lesson plans as a team: "I think it helped our team dynamic. For us to bond, work together and learn how to do that and it also just helped us throughout the whole semester, being able to look back on it as a reference and it really kind of got us thinking about what to teach to the kids." Even though the activity was described as stressful by many of the students, after the training program they recognized that it was a beneficial experience that improved their team dynamic.

Some students also reported that their service-learning teams were different from groups in other classes because they learned they could actually rely on their teammates. One student stated, "I've worked in teams before, but it was the kind of thing where the one person does everything and everyone just kind of slacks off. ... [In this situation], we all had learn to do our part and to pull our weight." One student even reflected that the collective learning activities allowed the student to see that "the most beneficial aspect was learning how to support other teammates in terms of their part of the lesson." Teams served as a source of support, so when the students felt stressed, they could rely on their teammates to help them prepare for training activities and eventually the service-learning experience.

Students also found critical reflection to be supportive during skill building because they received feedback from instructors and peers during the collective learning activities that helped them reflect on their successes and shortcomings. One student said, "we kind of learned from our mistakes when we were teaching in the mock lesson and so we were able to change it and do it more efficiently when we were teaching in the community." Another student said, "having [my peers] give me feedback on ... what to change and what to keep was really, really helpful.” In addition to benefitting from peer feedback, students also found it useful to watch their peers because they could compare their own performance with that of other students and learn from the performance of others. Reflection during the pre-service-learning training program allowed students to hone their skills before teaching in the community and cope with the stress of new teaching experiences.

While the course design was rigorous and challenging, it also served as a source of support during skill building. One student said, "We were taught pretty much everything that we needed to know to prepare us to teach the children. At first it was kind of overwhelming, because we didn't know what we were, kind of, getting into, but they taught us the proper knife skills. They taught us about planning. They taught us about important things to think about when teaching in front of the class and classroom management. They went through the manual that the kids were going to Journal of the Scholarship of Teaching and Learning, Vol. 17, No. 3, July 2017. josotl.indiana.edu 
have, and we practiced cooking every week as a team, and team work and team building." Ultimately, the pre-service-learning training program design allowed students to work in teams to build nutrition education skills and their confidence in those skills, preparing them for the servicelearning experience.

\section{Discussion}

The pre-service-learning training program was designed to improve students' skills and confidence in those skills. The service-learning experience had already been shown to improve student selfefficacy in teaching nutrition education (Cooke et al., 2015; Goodell, Cooke, \& Ash, 2016), but we found that additional experience and training through the pre-service-learning training program also contributed to an increase in students' self-efficacy. The layered learning approach gave students the opportunity to build skills incrementally before the service-learning experience began. While students reported feeling stressed by the rigor of the program, their teams and the regular critical reflection helped mitigate that stress. Ultimately, students reported that the pre-servicelearning training program prepared them for teaching in the community. We believe students' learning can be attributed to the design of the pre-service-learning training program, specifically, the incremental skill building through layered learning activities and incorporation of Bandura's four sources of self-efficacy: vicarious experience, verbal persuasion, mastery, and physiological/ emotional state (Bandura, 1977).

Instructors at higher education institutions can create similar programs with disciplinespecific goals to fit their students' needs and the class' learning objectives. Because it takes individuals time to process and respond to feedback (Bandura, 1977), the layered learning structure this training program allowed for students to build skills gradually over the course of the training period, rather than when they teach their first lesson in the community. This layered learning course design differs from Nunley's Layered Curriculum in which students choose from a pool of activities of varying complexity and are graded based on the number and complexity of the activities completed, allowing them to tailor their own learning (Nunley, 2003). Rather, in the preservice-learning training layered learning design, all the activities were required to fully train students for the service-learning experience, though they did have different grade weights based on the complexity of the task. Still, the principle is the same: when you present students with layers of activities that build upon each other, you give students the opportunity to accomplish each learning goal, even when teaching students of varying prerequisite knowledge (Nunley, 2003). It is important for students to attribute their successes to skills, rather than chance, and for opportunities to build self-efficacy to be varied in nature (Bandura, 1977). Likewise, these layered learning activities provided students with incremental and varied realistic circumstances that serve as opportunities to succeed, therefore increasing self-efficacy in the skills associated with those successes.

The basic activities taught students key concepts related to the service-learning course objectives, such as what to expect in the service-learning experience. In this training program, we provided this basic knowledge of the service-learning experience through vicarious experiences, allowing students to view and discuss videos clips of former students with similar background experience, teaching the same curriculum in a community setting. Using former students as models is most effective in building self-efficacy because students can relate to individuals like themselves Journal of the Scholarship of Teaching and Learning, Vol. 17, No. 3, July 2017. josotl.indiana.edu 
(Tschannen-Moran \& Hoy, 2007). Verbal group reflection paired with these examples allowed students to critique previous students' performance, suggesting what they thought was effective and what they would do differently in the same situation. Not only did these basic activities serve as an introduction to the course, but students also began to build self-efficacy through these vicarious experiences by seeing peers succeeding, showing students they, too, were capable of successfully completing the service-learning experience (Wood \& Bandura, 1989).

The directed activities provided students with opportunities to develop and apply their knowledge and skills, while beginning to gain mastery of these skills. During these directed activities, students worked with their teammates to build key skills related to their service-learning project, such as how to purchase ingredients for healthy meals on a small budget and how to prepare engaging, organized lesson plans. As novices, students take longer to complete tasks and are more prone to errors (Ackerman, 2007), so these lower-stakes directed activities play an important role in skill building. These activities fit into the middle of the three-stage Model of Domain Learning, between acclimation and proficiency, allowing students, through practice, to become competent in these directed skills (Alexander, 2003). It is therefore important to recognize that while students might be proficient in their discipline-specific knowledge, they might be just becoming competent in these new skills related to the service-learning experience.

Finally, collective activities allowed students to use, improve, and combine their skills to effectively teach nutrition to community members. This is where students demonstrated their mastery, which is the most influential source of self-efficacy (Tschannen-Moran \& Hoy, 2007). Since students' self-efficacy increases when they succeed (Bruning et al., 2010), the pre-servicelearning training program purposefully included multiple opportunities for students to succeed, in the form of mock teaching experiences. To improve skill and self-efficacy, students experienced verbal persuasion in the form of positive and constructive feedback from instructors and peers after each collective activity. Even if students did not succeed at first, they had several opportunities to do so before they began their service-learning experience. Similarly, many teachers claim to learn the most about classroom and behavior management during in-class mock experiences, followed by actual fieldwork (Stough, 2015). Likewise, the students interviewed in this study claimed that these collective activities were most beneficial at preparing them for the service-learning experience. There was still some mastery during the directed and collective activities, but the overall purpose of these collective activities was to allow for development and practice of skills to prepare for the service-learning experience, and more globally, for future careers in nutrition education. This follows the trend that as teachers become more skilled and build self-efficacy through mastery experiences, the other three sources of self-efficacy have less of an impact on their self-efficacy (Tschannen-Moran \& Hoy, 2007).

In addition to layered learning activities, we found that a balance between stress and support is necessary for student growth and skill development, which relates to the physiological and emotional sources of self-efficacy. Stress is unavoidable when students are introduced to new situations, such as student teaching (Murray-Harvey et al., 2000). It typically has a negative connotation and is most often associated with the destructive response it can generate, but stress can also generate a productive, positive response or “eustress” (Gibbons, 2012; Hargrove, Becker, \& Hargrove, 2015; Lazarus \& Folkman, 1984), serving as a motivator for performing at an optimum level (Gibbons, Dempster, \& Moutray, 2008). The degree to which individuals view stress as positive (eustress) varies within individuals (Lazarus \& Folkman, 1984), and their ability Journal of the Scholarship of Teaching and Learning, Vol. 17, No. 3, July 2017. josotl.indiana.edu 
to cope with stress, whether negative (distress) or positive (eustress), is determined by the personality; self-efficacy; and perceived control, support, and coping style (Gibbons, 2012). While there is no magic formula for the appropriate amount of eustress, a supportive course design and learning environment can help mitigate this process.

Students reported that they were stressed by many of the training program activities due to the newness of the activities, compared to traditional class activities, and the scope of the material. While students often seek out peers as a response to course stress (Gibbons, 2012), faculty can provide a supportive peer framework within service-learning courses in order to minimize students' stress levels. In the pre-service-learning training program and the service-learning experience, students' teaching teams could provide this support. Specifically, students stated that their teammates helped them build skills in preparation for both the collective activities and the service-learning experience.

Critical reflection and feedback, both sources of verbal persuasion, were also influential in creating a supportive environment and limiting stress. Teammates provided constructive criticism after most of the collective learning activities, allowing students to learn from a peer who was going through the same experience, not just from their instructors. Building a learning environment that both encourages and requires self-reflection and peer feedback allows students to develop a supportive relationship with peers and instructors. This type of relationship has been shown to have a positive impact on academic performance (Murray-Harvey et al., 2000). While initially students might struggle with receiving constructive criticism, most of the time they are able to respond to feedback positively to improve their performance (Goodell, Cooke, \& Ash, 2016). Therefore, constructive criticism and supportive teams should be included in a pre-service-learning training program to help develop a positive psychological state in the students, which is key for an increase in student self-efficacy.

Students claimed that they were stressed during the pre-service-learning training program; however, when they reflected on the effectiveness of the training program after the servicelearning experience was completed, they recognized that the rigor of the program was necessary to fuel skill building. Therefore, the incremental, layered approach to learning, and the supportive environment to minimize stress had an impact on student's self-efficacy development, confirming what we saw quantitatively through previous research (Cooke et al., 2015). University instructors can use a similar format to provide students with experiential learning before the service-learning experience, ultimately leading to better-equipped students, and better outcomes for community participants and partners.

\section{Limitations}

While we employed a rigorous qualitative research design, our study was a volunteer sample. Because the sample was a volunteer sample, not all the students in that semester completed interviews. Therefore, there might be something different about the students who chose to participate in the interviews. To encourage participation in interviews, we provided an incentive for participation. Two years ago, we created the Iron Chef Challenge activity, which we believe was necessary for developing trust in teammates. Therefore, we opted to include only students who participated in the Iron Chef Challenge because others might have had a different experience

Journal of the Scholarship of Teaching and Learning, Vol. 17, No. 3, July 2017. josotl.indiana.edu 
with their teammates. While we did not interview students in subsequent semesters, we have confirmed these findings through informal end-of-semester focus groups.

\section{Implications}

In light of this knowledge, instructors who desire to incorporate service-learning into a course may want to consider creating a pre-service-learning training component, especially if relatively untrained students are going to be educating in the community. This training should be organized with layered learning activities to gradually prepare their students for work with the community paired with a healthy level of stress and support to fuel skill building. Better-prepared students may lead to more effective service-learning experiences for all parties involved, potentially resulting in higher self-efficacy and skills for students, better relationships with community partners, and more beneficial outcomes for community members.

Weekly reflection discussions are also an important aspect of the supportive environment of the service-learning class, involving teammates, professors and community liaisons, in critical discussion of weekly successes and shortcomings while teaching lessons. While this study did not explore the impact of the reflection sessions, future work could determine what role the reflection sessions played in developing self-efficacy during the service-learning experience. As similar preservice-learning trainings are developed, future studies could determine the similarities and differences in training programs across disciplines.

\section{References}

Ackerman, P. L. (2007). New developments in understanding skilled performance. Current Directions in Psychological Science, 16(5), 235-239. doi: 10.1111/j.1467-8721.2007.00511.x

Alexander, P. a. (2003). The Development of Expertise: The Journey From Acclimation to Proficiency. Educational Researcher, 32(8), 10-14. doi: 10.3102/0013189X032008010

Ash, S. L., Clayton, P. H., \& Moses, M. G. (2008). Learning Through Critical Reflection: A Tutorial for Service-Learning Students.

Bandura, A. (1977). Self-efficacy: Toward a Unifying Theory of Behavioral Change. Psychological Review, 84(2), 191-215.

Bartholomew, K., Henderson, A. J. Z., \& and Marcia, J. E. (2000). Coded Semistructured interviews in Social Psychological Research. In H. T. Reis \& C. M. Judd (Eds.), Handbook of Research Methods in Social and Personality Psychology (1st ed., pp. 286-312). Cambridge: Cambridge University Press.

Ben-Peretz, M. (1995). Curriculum of teacher education programmes. In International encyclopedia of teacher and teacher education (2nd ed., pp. 543-547). Elsevier Science Ltd.

Journal of the Scholarship of Teaching and Learning, Vol. 17, No. 3, July 2017.

josotl.indiana.edu 
Bernadowski, C., Perry, R., \& Del Greco, R. (2013). Improving preservice teachers’ self-efficacy through service learning: lessons learned. International Journal of Instruction, 6(2), 67-86.

Bringle, R. G., \& Hatcher, J. A. (1995). A service-learning curriculum for faculty. Michigan Journal of Community Service Learning, 2(1), 112-122.

Bruning, R. H., Schraw, G. J., \& Norby, M. M. (2010). Cognitive Psychology and Instruction (5th ed.). Boston, MA: Pearson.

Cooke, N. K., Ash, S. L., Nietfeld, J. L., Fogleman, A. D., \& Goodell, L.S. (2015). Impact of a community nutrition service-learning course on students' nutrition education teaching selfefficacy. North American Colleges and Teachers of Agriculture Journal. 59(1), 28-33.

Cooking Matters. (2013). Cooking Matters 2013 Annual Review. https://cookingmatters.org/sites/default/files/CookingMatters_2013_AnnualReview_FOR_WEB. pdf

Driscoll, A., Holland, B., Gelmon, S., \& Kerrigan, S. (1996). An assessment model for servicelearning: Comprehensive case studies of impact on faculty, students, community and institutions. Michigan Journal of Community Service Learning, 3(1), 66-71.

Eyler, J., \& Giles, D. E. (1999). Where's the learning in service-learning? San Francisco, CA: Jossey-Bass.

Gibbons, C. (2012). Stress, Positive Psychology and the National Student Survey. Psychology Teaching Review, 18(2), 22-30.

Gibbons, C., Dempster, M., \& Moutray, M. (2008). Stress and eustress in nursing students. Journal of Advanced Nursing, 61(3), 282-290. doi: 10.1111/j.1365-2648.2007.04497.x

Goodell, L. S., Cooke, N. K., \& Ash, S. L. (2016). A qualitative assessment of the impact of a service-learning course on students' discipline-specific self-efficacy. Journal of Community Engagement and Higher Education, 8(2), 28-40.

Goodell, L. S., Stage, V. C., \& Cooke, N. K. (2016). Practical qualitatative research strategies: training interviewers and coders. Journal of Nutrition Education and Behavior, 48(8), 578-585. doi: 10.1016/j.jneb.2016.06.001.

Goulding, C. (1999). Grounded Theory: some reflections on paradigm, procedures and misconceptions, 44(0).

Hargrove, M. B., Becker, W. S., \& Hargrove, D. F. (2015). The HRD Eustress Model: Generating Positive Stress With Challenging Work . Human Resource Development Review , 14 (3 ), 279298. doi: 10.1177/1534484315598086

Journal of the Scholarship of Teaching and Learning, Vol. 17, No. 3, July 2017.

josotl.indiana.edu 
Lazarus, R. S., \& Folkman, S. (1984). Stress, Appraisal, and Coping (1st ed.). New York, NY: Springer Publishing Company, Inc.

Murray-Harvey, R., Slee, P. T., Lawson, M. J., Silins, H., Banfield, G., \& Russell, A. (2000). Under Stress: The Concerns and Coping Strategies of Teacher Education Students. European Journal of Teacher Education, 23(1), 19-35.

Nunley, K. F. (2003). Layered Curriculum Brings Teachers to Tiers. The Education Digest, 69(1), 31-36.

Stough, L. M. (2015). Persistent Classroom Management Training Needs of Experienced Teachers. Journal of the Scholarship of Teaching and Learning, 15(5), 36. doi: 10.14434/josotl.v15i5.13784

Tryon, E., Stoecker, R., Martin, A., Seblonka, K., Hilgendorf, A., \& Nellis, M. (2008). The challenge of short-term service-learning. Michigan Journal of Community Service Learning, 14(2), 16-26.

Tschannen-Moran, M., \& Hoy, A. W. (2007). The differential antecedents of self-efficacy beliefs of novice and experienced teachers. Teaching and Teacher Education, 23(6), 944-956. doi: 10.1016/j.tate.2006.05.003

Tucker, M. L., \& McCarthy, A. M. (2001). Presentation Self-Efficacy: Increasing Communication Skills Through Service-Learning. Journal of Managerial Issues, 13(2), 227-244.

Wood, R., \& Bandura, A. (1989). Social Cognitive Theory of Organizational Management. Academy of Management Review. doi: 10.5465/AMR.1989.4279067

Yoder, K. M. (2006). A framework for service-learning in dental education. Journal of Dental Education, 70(2), 115-123.

Journal of the Scholarship of Teaching and Learning, Vol. 17, No. 3, July 2017.

josotl.indiana.edu 